\title{
Pengaruh Pencukuran Bulu Terhadap Bobot Komponen Karkas Domba Lokal Jantan yang Dikandangkan
}

\author{
The effect of Shaving on Carcass Weight of Local Tup in The Cage \\ Irmawaty \\ Jurusan Ilmu Peternakan, Fakultas Sains dan Teknologi \\ Universitas Islam Negeri Alauddin Makassar \\ Korespondensi Email: irmawaty.majid@gmail.com
}

\begin{abstract}
ABSTRAK
Penelitian ini bertujuan untuk mengetahui pengaruh pencukuran bulu terhadap bobot komponen karkas domba lokal jantan. Penelitian ini menggunakan 10 ekor ternak domba jantan hasil persilangan Merbas dengan Ekor Gemuk, yang berumur kurang lebih 1 tahun dengan kisaran bobot badan 13-20 kg. Ternak tersebut ditempatkan ke dalam kandang individual model panggung berukuran $75 \times 75 \times 75 \mathrm{~cm}$. Rancangan Penelitian yang digunakan adalah uji statitik " $\mathrm{t}$ " dengan 2 perlakuan dan 5 ulangan. Adapun perlakuan tersebut adalah $\mathrm{Ck}=$ Bulu dicukur, dan $\mathrm{t} c \mathrm{k}=$ Bulu tidak di cukur. Hasil analisis analissis statistik menunjukkan bahwa pencukuran bulu memeberikan pengaruh yang nyata terhadap bobot komponen karkas bagian Neck, Shoulder, Ribs, Flank, Loin, Leg, Breast dan Shank ternak Domba Jantan Lokal hasil perilangan merbas dengan ekor gemuk.
\end{abstract}

Kata kunci: Bobot Komponen Karkas, Domba Jantan, Pencukuran Bulu,

\begin{abstract}
The aim of this study is to khow the influence of epilation against local sheep carcass component weights of males. The study used 10 tail cattle Rams results yet Fat-tailed Merbas a cross, which was more or less 1 year with a range of body weights 13-20 $20 \mathrm{~kg}$. Cattle land placed into individual cages model stage-sized $75 \times 75 \times 75 \mathrm{~cm}$. Research Design used is the test statistics " $\mathrm{t}$ " with 2 treatments and five replicates. As for the treatment is $\mathrm{Ck}=$ Fur shaved, and $\mathrm{t}=$ not in Feather ck shaving. The results of the analysis of analissis statistics show that epilation give real effect against weight of carcass components section of the Neck, Shoulder, Ribs, Flank, Loin, Leg, Breast and Shank of cattle to local Rams hassil perilangan merbas with tail fat.
\end{abstract}

Keywords: Carcass Component Weight, Fur Shaving, Male Sheep

\section{PENDAHULUAN}

Kebutuhan akan daging meningkat seiring dengan membaiknya taraf hidup dan meningkatnya kesadaran masyarakat akan pentingnya nilai gizi untuk kesehatan sehingga 
untuk mengimbangi permintaan terebut, maka dipandang perlu suatu upaya meningkatkan mutu produksi ternak

Salah satu jenis ternak penghasil daging yang dapat dikembangkan untuk memenuhi kebutuhan daging ternak adalah domba. Ternak domba tergolong ternak ruminansia kecil yang mampu mengkonveri hijauan ke dalam bentuk daging yang bernilai gizi tinggi. Untuk mendukung kemampuan produki ternak terebut maka pada umumnya dapat dilakukan melalui penyediaan bibit yang baik, perbaikan makanan dan tata laksana pemeliharaan.

Tingkat produksi ternak dapat diukur dari laju pertumbuhannya. Laju pertumbuhan seekor ternak tidak terlepas dari faktor lingkungan ekitar ternak tersebut hidup yang walaupun secara genetik, kemampuan produksi ternak tinggi, tetapi tanpa didukung oleh faktor lingkungan yang memadai, maka kemampuan genetik tersebut sulit diekpresikan. Hal ini sesuai dengan pendapat atmadilaga (1981) bahwa pertumbuhan seekor ternak sangat dipengaruhi oleh faktor genetik dan faktor lingkungan. Selanjutnya dinyatakan bahwa faktor lingkungan memainkan peranan penting yang sanngat bear yaitu sekitar 70\% edangkan faktor genetik 30\%. Faktor lingkungan yang dimaksud adalah pakan, pemeliharaan, suhu lingkungan dan kelembapan udara.

Faktor lingkungan yang banyak mempengaruhi produksi ternak adalah suhu dan kelembaban udara yang tinggi terutama di daerah-daerah tropis seperti di Indonesia khususnya di daerah Sulawesi Tengah yang memilki suhu rata-rata $37^{\circ} \mathrm{C}$ dengan kelembaban udara rata-rata 42,56\%. Lebih lanjut dinyatakan bahwa suhu tertinggi dicapai pada pukul 12.00 -13.00. Hal ini akan berpengaruh buruk terhadap produktivitas ternak karena secara tidak langsung akan mempengaruhi konsumsi pakan dan pertumbuhan.

Area Lembah Palu banyak dijumpai domba hasil persilangan Merba dan Ekor gemuk yang memilki bulu hampir sama dengan ciri-ciri domba merbas, yaitu bulunya panjang dan tebal serta tidak memperlihatkan adanya ekor yang gemuk. Ketebalan bulu ini akan berpengaruh terhadap fisiologi ternak, terutama dalam pelepasan pana yang elalu terjadi (oeharsono, 1976). Oleh Karena itu diupayakann pencukuran bulu, sehingga ternak mampu mempertahankan kondisi tubuh dengan cara memperbesar pembuangan pana tubuh yang berlebihan pada aat domba menerima cekaman pana dari lingkungannya.

Pencukuran merupan salah satu alternatif pendekatan yang dapat dilakukan melalui manajemen pemeliharaan ternak domba yang dapat memberikan keeimbangan produksi dan pembuangan panas, karena hilangnya bulu sebagai isolator dapat memperlancar 
pembuangan panas dari tubuh. Kemampuan untuk membuang panas dari tubuh bagi ternak-ternak yang dicukur akan lebih baik sehingga dapat mempertinggi daya tahan panas. Berdasarkan hal tersebut, maka dilakukan suatu penelitian tentang Pengaruh Pencukuran Bulu terhadap Bobot Komponen Karkas Domba Lokal Jantan yang dikandangkan. Berdasarkan latar belakang yang telah diuraikan diatas, maka rumusan masalahnya adalah bagaimana pengaruh pencukuran bulu terhadap bobot komponen karkas domba lokal jantan yang dikandangkan. Tujuan dari penelitian ini yaitu untuk mengetahui pengaruh pencukuran bulu terhadap bobot komponen karkas domba lokal jantan yang dikandangkan. Hasil penelitian ini diharapkan dapat dijadikan sebagai sumber informasi kepada berbagai pihak terkait pengaruh pencukuran bulu terhadap bobot komponen karkas domba lokal jantan yang dikandangkan

\section{METODE PENELITIAN}

\section{Jenis dan Lokasi Penelitian}

Penelitian ini dilaksanakan di lokasi Lapangan Golf Kelurahan Talise Kecamatan Palu Timur, Kotamadya Palu.

\section{Sumber dan Metode Pengumpulan Data}

Penelitian ini menggunakan 10 ekor ternak jantan hasil persilangan Merbas dan Ekor Gemuk yang berumur \pm 1 tahun dengan kisaran bobot badan 13-20 kg. Kandang yang digunakan adalah kandang terbuka dimana pada ke empat sisinya tidak memakai dinding penutup. Di dalam kandang utama tersebut terdapat kandang individual berbentuk panggung yang disekat sebanyak 10 petak dengan ukuran $75 \times 75 \times 75 \mathrm{~cm}$. Masing-masing kandang individual dilengkapi dengan tempat makan dan minum. Untuk menimbang ternak digunakan timbangan dacing berkapasitas $25 \mathrm{~kg}$ dengan skala ketelitian $100 \mathrm{~g}$ sedangkan untuk menimbang makanan dan komponen karkas digunakan timbangan duduk berkapasitas $3 \mathrm{~kg}$ dengan skala ketelitian $10 \mathrm{~g}$. Sebelum ternak ditempatkan ke dalam kandang, terlebih dahulu dilakukan sanitasi kandang yaitu dengan melakukan penyemprotan yang menggunakan desinfektan merek Neo Antisep dan untuk parasit cacing digunakan obat cacing merek Nemasol.

Selama penelitian berlangsung, setiap ternak masing-masing diberi ransum basal berupa hijauan jagung (zea mays) dan konsentrat dengan kadar protein kasar 11,09 \% dan TDN 66,3\%. Konsentrat dan hijauan jagung diberikan sebanyak 3\% dari bobot badan 
berdasarkan bahan kering. Konsentrat yag diberikan adalah campuran dari bungkil kelapa, jagung giling dan dedak padi. Pemberian hijauan dilakukan setelah konsentrat habis terkonsumsi. Adapun susunan dan komposisi kimia penyusunan ransum tertera pada tabel 1 dan 2.

Tabel 1. Susunan Komposisi Kimia Ransum (\% dalam Bahan Kering)

\begin{tabular}{llllll}
\hline \multirow{2}{*}{ No } & \multirow{2}{*}{ Komposisi } & \multicolumn{4}{c}{ Bahan Makanan } \\
\cline { 3 - 6 } & $\begin{array}{c}\text { Hijauan } \\
\text { Jagung }\end{array}$ & $\begin{array}{c}\text { Bungkil } \\
\text { Kelapa }\end{array}$ & $\begin{array}{c}\text { Jagung } \\
\text { Giling }\end{array}$ & $\begin{array}{c}\text { Dedak } \\
\text { padi }\end{array}$ \\
\hline 1 & Bahan Kering* & 22,00 & 86,00 & 86,00 & 86,00 \\
2 & Protein* & 9,8 & 19,12 & 10,05 & 133,05 \\
3 & Serat KasarP & 29,60 & 12,10 & 2,50 & 11,60 \\
4 & Lemak* $^{*}$ & 1,90 & 10,20 & 4,70 & 14,10 \\
5 & BETN* $^{*}$ & 49,52 & 49,70 & 79,8 & 48,70 \\
6 & Phospor* $_{7}^{*}$ & 0,03 & 0,56 & 0,23 & 1,30 \\
8 & Kalsium $^{*}$ & 0,06 & 0,18 & 0,02 & 0,10 \\
\hline
\end{tabular}

Keterangan: * Dihitung berdasarkan hasil analisis laboratorium Fakultas pertanian Untad, 1997.

** Dihitung berdasarkan petunjuk hartadi, dkk (19993) dengan menggunakan rumus 2 dan 4.

Tabel 2. Susunan penyusun Ransum Percobaan (\% Bahan Kering)

\begin{tabular}{lc}
\hline \multicolumn{1}{c}{ Bahan Makanan } & Komposisi \\
\hline Hijauan Jagung & 70,00 \\
Bungkil Kelapa & 15,00 \\
Dedak Padi & 10,00 \\
Jagung Giling & 5,00 \\
\hline Jumlah & 100 \\
\hline Protein & 11,09 \\
TDN & 66,30 \\
\hline
\end{tabular}

Dihitung berdasarkan Tabel 1.

Penelitian ini dilakukan dalam 3 tahap, yaitu tahap pendahuluan selama 14 hari, tahap pemberian perlakuan selama 6 minggu dan tahap pengumpulan data komponen karkas selama 1 hari. Adapun tujuan dari tahap pendahuluan menurut Ranjhan (1981); Han, dkk (1990) dalam Proyono (1997) adalah.

a. Untuk membiasakan ternak dengan keadaan lingkungan baru

b. Untuk membiasakan ternakan dengan pakan yang dicobakan

c. Untuk menghilangkan pengaruh pakan sebelumnya 
d. Untuk menentukan jumlah pakan yang akan diberikan pada saat percobaan

Penelitian ini menggunakan uji statistik " $\mathrm{t}$ " dengan 2 perlakuan dan setiap perlakuan diulang sebanyak 5 ulangan. Perlakuan yang diberikan adalah sebagai berikut :

a. $\mathrm{Ck}=$ Bulu dicukur

b. Tck $=$ Bulu Tidak dicukur

\section{Metode Pencukuran}

Akhir periode pendahuluan, ternak percobaan yang mendapat perlakuan bulu secara manual hingga mencapai panjang bulu $\pm 2 \mathrm{~cm}$. Setelah dicukur secara manual, bulu diratakan dengan menggunakan alat cukur eletrik

\section{Metode Pemotongan}

Sebelum ternak dipotong terlebih dahulu dipuasakan 12 jam untuk mengurang isi saluran pencernaan dan untuk menghindari pencemaran pada karkas oleh isi saluran penccernaan. Pemotongan dilakukan dengan memotong, vena jugularis, vena karotis dan vena arteri. Kepala dipisahkan dari tubuh pada sendi occipito atlantis, kaki depan pada sendi carpo metacarpal, dan kaki belakang pada sendi tarso metatarsal. Tubuh ternak digantung pada sendi belakang dekat tendo achiles, kulit dilepas, kemudian dibuat sayatan lurus ditengahtengah perut dan isi rongga dada serta rongga perut dikeluarkan kecuali ginjal kemudian karkas ditimbang ( Herman, 1981).

Potongan primal karkas domba berupa bahu (shoulder), Leher (neck), Rusuk (ribs), Lengan (shank) dan dada (ribs) termasuk dada bagian depan, sedangkan paha (leg termasuk sirloin), pinggang (loin), sisi (flank) termasuk karkas bagian belakang (soeparno, 1984)

\section{Peubah yang diamati}

Neck = Adalah komponen karkas yang terdapat pada bagian leher mulai dari vertebrae cervicalis ke-1 sampai vertebrae cervicalis ke-7

Shoulder $=$ adalah komponen karkas yang terdapat pada bagian bahu mulai dari vertebrae cervicalis ke 7 sampai pertengahan costae ke 5 dan ke 6

Ribs = Adlah komponen karkas yang terdapat pada bagian rusuk mulai dari pertengahan costae ke 5 dan ke 6 sampai costae ke 12-13 berbatasan dengan breast

Loin $=$ adalah komponen karkas yang terdapat pada bagian pinggang mulai dari costae ke 13 sampai vertebrae cervicalis ke 8 
Leg = adalah komponen karkas yang terdapat pada bagian paha mulai dari vertebrae ke 9 sampai pada sendi patella.

Flank $=$ adalah komponen karkas yang terdapat pada sisi mulai dari proyeksi ujung costae ke 13 yang ditarik lurus dari ujung dada berbatasan dengan pangkal paha

Breast $=$ adalah komponen karkas yang terdapat pada bagian dada (bagian starnum lurus ke belakang hingga proyeksi dari vertebrae lumbalis ke 6)

Shank = adalah komponen kasrkas yang terdapat pada bagian lengan (bagian persendian antara humerus dan radius ulna sampai carpus)

\section{HASIL DAN PEMBAHASAN}

Rata rata bobot komponen karkas domba lokal jantan hasil persilangan merbas dengan ekor gemuk dari masing-masing perlakuan tertera pada tabel 3.

Tabel 3. Rata-rata Bobot Komponen Karkas Domba Jantan Hasil Persilangan merbas dengan ekor Gemuk (kg/ekor)

\begin{tabular}{lcc}
\hline \multicolumn{1}{r}{ Komponen } & Cukur & Perlakuan \\
& 0,914 & Tidak Cukur \\
\hline Neck & 2,592 & 0,732 \\
Shoulder & 1,126 & 2,072 \\
Ribs & 0.818 & 0,896 \\
Loin & 2,862 & 0,642 \\
Leg & 0,428 & 2,286 \\
Flang & 0,794 & 0,338 \\
Breast & 1,106 & 0,634 \\
Shank & & 0,894 \\
\hline
\end{tabular}

Sumber: Data Primer

Tabel 3 menunjukkan bahwa rata-rata bobot badan komponen karkas dari masingmasing perlakuan, yang tertinggi diperoleh pada perlakuan domba yang dicukur (Ck), kemudian diikuti oleh perlakuan yang tidak dicukur (TCk). Hasil analisis statistik dengan uji " $\mathrm{t}$ " menunjukkan bahwa pencukuran bulu dapat memberikan pengaruh yang nyata $(\mathrm{P}<0,05)$ terhadap bobot komponen karkas.

Keadaan ini menunjukkan bahwa domba yang dicukur mampu mengkonsumsi pakan yang lebih banyak, sehingga opertambahan bobot komponen karkas dapat lebih baik sebagai manifestati dari adanya pertambahan bobot badan. Hal tersebut dikarenakan domba yang dicukur lebih efektif mengeluarkan panas tubuh melalui konveksi maupun secara konduksi sehingga energi ransum yang dukonsumsi tidak banyak digunakan untuk proses pemenuhan hidup pokok. 
Pencukuran bulu dapat menurunkan pembuangan panas melalui evaporasi, menurunkan insulasi bulu, meningkatkan konsumsi pakan dan pertumbuhan ( Priyono, 1977). Sebaliknya bagi domba yang tidak dicukur akan mengalami kesulitan dalam pembuangan panas tubuh secara normal untuk memperoleh homeothermanya, sehingga menyebabkan domba yang tidak dicukur cenderung lebih sedikit memanfaatkan energi ransum yang dikonsumsi untuk proses pertumbuhan, tetapi justru lebih banyak dimanfaatkan untuk kebutuhan hidup pokok dan proses pelepasan panas tubuh.

Hafez(1986) menyakan bahwa makin meningkat suhu lingkungan efisiensi penggunaan energi ransum makin berkurang sehingga menghambat pertumbuhan yang pada gilirannya kan menyebabkam rendahnya bobot komponen karkas.

\section{KESIMPULAN}

Berdasarkan hasil penelitian maka dapat ditarik kesimpulan sebagai berikut;

1. Pencukuran bulu pada ternak domba yang dicukur memberikan pengaruh yang nyata terhadap bobot komponen karkas dibandingkan domba yang tidak di cukur

2. Domba yang dicukur dapat memberikan bobot komponen karkas yang lebih tinggi bila dibandingkan dengan ternak yang tidak dicukur

Hasil penelitian disarankan kepeda peternak, bahwa pencukuran bulu dapat dilakukan pada ternak sebagai slah satu alternatif untuk meningkatkan produksi ternak.

\section{DAFTAR PUSTAKA}

Hartadi., Reksohadiprojo, H., dan Tilman, A.D. 1993. Tabel Komposisi Pakan untuk Indonesia. Gadja Mada University Press, Yogyakarta

Herman. 1981. Kualitas Karkas Domba Lokal Hasil penggemukan. Prosiding Seminar penelitian Peternakan. Balai Penelitin dan Pengembangan Peternakan, Bogor

Priyono, A. 1997. Pengaruh Pencukuran dan Level Energi Ransum terhadap Performans Domba Lokal Jantan. Thesis. Program Pascasarjana Universitas Padjadjaran, Bandung Soeparno. 1994. Ilmu dan Teknologi Daging. Gadjah Mada University Press, Yogyakarta. Sudjana. 1992. Metode Statistik. Tarsito Bandung. 